\title{
FAIR ACCESS TO REGULATED PROFESSIONS: \\ DECODING THE TRANSITION OF MIRGRANT CAREGIVERS TO NURSING IN ONTARIO
}

\author{
By \\ Gowsiga Thirunavukkarasu, BA Honours Political Science, York University, 2011 \\ BA Honours Human Rights and Equity Studies York University, 2012 \\ A Major Research Paper \\ presented to Ryerson University \\ in partial fulfillment of the requirements for the degree of \\ Master of Arts \\ in the Program of \\ Immigration and Settlement Studies
}

Toronto, Ontario, Canada, 2013

(C) Gowsiga Thirunavukkarasu 2013 


\section{AUTHOR'S DECLARATION}

\section{AUTHOR'S DECLARATION FOR ELECTRONIC SUBMISSION OF A MAJOR RESEARCH PAPER (MRP)}

I hereby declare that I am the sole author of this Major Research Paper. This is a true copy of the MRP, including any required final revisions, as accepted by my examiners.

I authorize Ryerson University to lend this MRP to other institutions or individuals for the purpose of scholarly research.

I further authorize Ryerson University to reproduce this MRP by photocopying or by other means, in total or in part, at the request of other institutions or individuals for the purpose of scholarly research.

I understand that my MRP may be made electronically available to the public.

Gowsiga Thirunavukkarasu 


\title{
FAIR ACCESS TO REGULATED PROFESSIONS: DECODING THE TRANSITION OF MIGRANT CAREGIVERS TO NURSING IN ONTARIO
}

\author{
Gowsiga Thirunavukkarasu \\ Master of Arts 2013 \\ Immigration and Settlement Studies \\ Ryerson University
}

\begin{abstract}
\end{abstract}
The Live-in Caregiver program provides a gendered pathway to permanent residency in Canada for women who are internationally trained nurses. Upon attaining permanent residency and open work permits, internationally trained nurses can become registered members with the College of Nurses of Ontario, which will allow them to re-enter the nursing profession. However, in light of recent amendments to the registration regulation by the College of Nurses of Ontario issues of unequal treatment for international applicants arise. This paper examines the regulation of the Live-in Caregiver Program, and the recent amendments to the registration regulation by the College of Nurses of Ontario, to present the systemic oppression and discrimination which creates barriers for internationally trained nurses to their transition from caregiving to nursing in Ontario. Conclusions state that amendments to the regulatory policies must occur to eliminate the inequalities against internationally trained nurses.

Keywords: Gender• In-Direct Pathways to Nursing• Live-in Caregiver Program• College of Nurses of Ontario $\bullet$ Internationally Trained Nurses 


\section{ACKNOWLEDGEMENTS}

This MRP would not have been possible without the guidance and support of several individuals who have extended their time, knowledge, resources, and support. I would like to acknowledge:

My mentor: It is with immense gratitude that I acknowledge the support of Dr. Thaddeus Hwong, Associate Director of the School of Administrative Studies, for enlightening me with the importance of policy analysis through interdisciplinary research. Thank you for taking me under your wing throughout the duration of my academic endeavors.

The Fairness Commissioner of Ontario: I consider it a great honour to have had the opportunity to work with the Honorable Jean Augustine, the Fairness Commissioner of Ontario and her wonderful staff at the Office of the Fairness Commissioner. I have no words to describe my gratitude for the mentorship I received during my short time at the Office of Fairness Commissioner. Thank you for granting me the opportunity to gain a wealth of knowledge on the field of credential recognition for internationally trained professionals. Thank you for allowing me to humanize my work, and examine the practical implications of a systemic problem.

My supervisor: I greatly appreciate the critical insights and enthusiastic support of Dr. Sedef Arat-Koc, Associate Professor in the Department of Politics and Public Administration at Ryerson University. You have fuelled my argument for human rights advocacy and equality for all members of society regardless of their citizenship status. Thank you for sharing your abundance of knowledge with me.

My guru: Finally, I would like to thank my guru Smt. Kawsalya Rajakumar for opening my eyes to the beauty of Bharathanatyam. Through your wisdom and guidance I have learned that fine arts can act as a towering agent of advocacy to showcase the suffering of marginalized populations. Thank you for allowing me to take great pride my heritage and culture in an age where assimilation has become of vital importance to societal inclusion. 


\section{DEDICATION}

would like to dedicate this paper to internationally trained nurses who migrate to Canada under the Live-in Caregiver Program, and undergo countless systemic discriminations and inequalities during their transition to nursing. Your challenges to the indirect pathway to nursing are inextricably interwoven in this paper. 


\section{CONTENTS}

AUTHOR'S DECLARATION

ABSTRACT

iii

ACKNOWLEDGEMENTS

iv

DEDICATION

CONTENTS

vi

LIST OF ACRONYMS

Viii

LIST OF FIGURES

ix

\section{INTRODUCTION}

A. BACKGROUND TO THE PAPER

B. RESEARCH QUESTION

C. THEORETICAL FRAMEWORK

D. METHODOLOGY

E. SIGNIFICANCE AND ORGANIZATION OF PAPER

F. SCOPE AND LIMITATIONS

G. TERMINOLOGY

II. IMPEDIMENTS TO THE TRANSITION FROM CAREGIVING TO NURSING IN ONTARIO

H. COMPLICATIONS TO THE COMPLETION OF THE LIVE-IN CAREGIVER PROGRAM

1. Understanding the Regulation of the Live-in Caregiver Program

2. Barriers to the Completion of the Live-in Caregiver Program

I. BARRIERS TO NURSING LICENSURE FOR INTERNATIONALLY TRAINED NURSES

1. Understanding the Registration Regulation by the College of Nurses of Ontario 
2. Barriers to Nursing Licensure

III. RECOMMENDATIONS

J. THE URGENCY TO END ‘BAD’ REGULATORY PRACTICES

K. RECOMMENDATIONS TO IMPROVE REGULATIONS GOVERNING

CAREGIVIERS UNDER THE LIVE-IN CAREGIVER PROGRAM

L. RECOMMENDATIONS TO IMPROVE REGULATION GOVERNING INTERNATIONAL APPLICANTS WITH THE COLLEGE NURSES OF ONTARIO 54

REFERENCES 


\section{LIST OF ACRONYMS}

The following table describes the acronyms used throughout the paper. The page numbers make reference to the first time each acronym was used.

\begin{tabular}{|l|l|l|}
\hline Acronym & Meaning & $\begin{array}{l}\text { Page } \\
\text { Number }\end{array}$ \\
\hline CIC & Citizenship and Immigration Canada & 2 \\
\hline CNO & College of Nurses of Ontario & 7 \\
\hline HRSDC & Human Resources and Skills Development Canada & 32 \\
\hline LCP & Live-in Caregiver Program & 2 \\
\hline LMO & Labour Market Opinion & 32 \\
\hline OFC & Office of the Fairness Commissioner & 49 \\
\hline SER & Standard Employment Relation & 13 \\
\hline TFWP & Temporary Foreign Worker Program & 2 \\
\hline
\end{tabular}




\section{LIST OF FIGURES}

The following describes the figures used throughout the paper.

\begin{tabular}{|l|l|}
\hline Figure & Page \\
\hline Figure 1: The transition from caregiving to nursing in Ontario & 19 \\
\hline
\end{tabular}





\section{INTRODUCTION}

\section{A. BACKGROUND TO THE PAPER}

\section{The history of domestic labour in Canada}

Immigration to Canada was not ethnically diverse for most of history since

Confederation. During the early 1900s Canada's preference for migrant domestic workers from

Britain, and Central/Eastern Europe was prevalent through heavily racialized immigration patterns. However, shortly following the Second World War in the 1950s economic need and persistent demands from middle class Canadian families for paid reproductive labour opened the gates for ethnic-cultural diversity in Canadian immigration. During this period, Canada increased its intake of racialized immigrants in domestic work, and invited migrant domestic workers from countries such as Greece, Jamaica and Barbados. The face of Canadian immigration continued to rapidly change during the 1960s, which proved to be an age of economic expansion for Canada. By 1973 the government was supplying white middle class families with a steady stream of captive labourers with Temporary Employment Authorizations (Cohen, 2000, p. 80). The irony of this "progression" and racially "inclusive" immigration policy is embedded in the lack of status extended to migrant women of colour. Under this context racialized migrant domestic workers, from developing countries could only enter Canada with temporary worker permits that did not grant them the right to apply for landed immigration status. On the other hand, British and European migrant domestic workers who migrated to Canada during the early 1990s had (previously) been granted permanent residency in exchange for performing reproductive labour for their employers (Cohen, 2000, p. 81). Thus, the exclusion of women of colour from larger society is prevalent through the lack of immigration status extended during this period. 
Following the mobilization of immigrant and women's rights movements advocating against the repressive employment conditions, the government introduced the Foreign Domestic Movement in 1981, offering women of colour the possibility of applying for landed immigrant status. Although this served as a victory, several domestic workers suffered exploitative and oppressive work environments. This condition was catalyzed by the temporary work permits and the Foreign Domestic Movement's mandatory requirement for caregivers to live-in the residence of the employers. Fearing deportation, these women colour remained in their live-in positions. Eleven years after its introduction, the Foreign Domestic Movement was terminated and was superseded by the Live-in Caregiver program (LCP).

Under immigration legislation, the LCP is a stream of the Temporary Foreign Worker Program (TFWP), which permits the temporary migration of workers into the Canadian economy to fulfil short-term labour shortages. Citizenship and Immigration Canada (CIC) has defined live-in caregivers as temporary foreign workers who are qualified to provide care for children, elderly persons and disabled persons in private homes without supervision (Citizenship and Immigration Canada, 2013b, para. 1). The unique structure of Canada's LCP provides migrant workers to apply for permanent residency following the completion of the LCP and its according employment requirements.

Speaking on the rights, and access to services for temporary foreign workers, Ratna Omidvar, the President of Maytree Foundation argues that, " A program (referring to TFWPs) which brings in individuals who have few rights as temporary residents, who have limited or no access to services and who are not able to advocate for themselves is not the Canadian way" (Omidvar, 2009, p. 1). The LCP continues the tradition of regulating the migration of gendered domestic labour into Canada, while (indirectly) endorsing a system of discrimination (causing 
impediments to caregivers' transition to nursing) (Cohen, 2000, p. 80). Although the LCP was modified to include a pathway to permanent residency for migrant domestic workers, it continued to uphold traditions of mandatory live-in requirements and elements of temporary immigration status while completing the employment requirements for permanent residency. The collective impacts of these regulatory requirements negatively affect caregivers, and results in extra-vulnerability to exploitation, harassment and the violation of caregivers' employment rights by employers.

Caregiving is considered "private" labour while nursing is considered a "public" form of labour, which is often labeled as a "health care" rather than as "care-giving". The private/public dichotomy is fundamental to building an argument for the marginalization of and subordination of women to traditional and gendered roles are caregivers in both spheres. In addition, it is interesting to note that women dominate both healthcare and caregiving professions.

Both caregivers and nurses experience the gendered and often precarious nature of 'caregiving' work in the private sphere of domestic work, and the public sphere of healthcare.

Under this context, gender refers to socially constructed differences in society between men and women. Their experiences are linked when internationally trained nurses migrate to Canada through the LCP with aspirations to re-enter the nursing profession in Canada upon completion of the LCP. Nursing may be undervalued in the healthcare profession; it is viewed as more favourable than caregiving work since it is better compensated. However, credential recognition, which leads to nursing licensure, is crucial to the transition from caregiving to nursing in Ontario.

\section{International nurse migration through the LCP and the negative impacts of the program} The Canadian Research Institute for the Advancement of Women, an advocacy group that undertakes research for social justice and change in women's lives states that there has been 
a significant increase in foreign born and visible minority women in Canada (Hick, 2007, p. 148). A large number of caregivers, who enter the private labour markets of Ontario, are internationally trained nurses who hope to re-enter the nursing profession (Walton-Roberts \& Hennebry, 2012, p. 2). The LCP theoretically serves as a good policy, which provides the possibility for an indirect career path for internationally, trained nurses following the completion of the LCP. However, the practical implications through the regulation of the program prove that the LCP creates 'bad' regulatory practices that negatively impact the fundamental rights of migrant women.

Margaret Walton-Roberts and Jenna Hennebry (2012) explore indirect pathways to nursing in Canada through the LCP. They state that sectors of the labour market are increasingly "feminized," and that this heavily resonates with traditional notions of "women's work" and related work conditions (Walton-Roberts \& Hennebry, 2012, p. 2). They examine internationally trained nurses from India, who enter Ontario as international students through the Canadian Experience Class. They additionally examine internationally trained nurses from the Philippines, who enter Ontario through the LCP. Walton-Roberts and Hennebry state that the entry of nurses through the LCP is not a new phenomenon. On the topic of internationally trained nurses who take indirect pathways into nursing practice, they state that the migration of skilled female labour such as nurses through the LCP is sometimes the only available pathway to enter Canada (Walton-Roberts \& Hennebry, 2012, p. 4). Walton-Roberts and Hennebry explain that internationally trained nurses often find the LCP as the only other alternative since internationally trained nurses can face trouble migrating to Canada as principal applicants for permanent, landed status (Walton-Roberts \& Hennebry, 2012, p. 4). They argue that Canada's current immigration system is competitive and places an increased emphasis on educational 
credentials, and language skills. The program offers women who can't enter Canada as principle applicants for permanent, landed status the opportunity to engage in paid employment, and eventually gain permanent residency, and transition to nursing (Walton-Roberts \& Hennebry, 2012, p. 22). Internationally educated nurses entering Canada as caregivers enter private labour markets where they conduct devalued care work under unregulated employment conditions. Although the LCP provides a pathway to permanent residency, the care work these women conduct are increasingly racialized and gender. The unregulated nature of the private work environments may cause delays in time for access to the nursing profession (Walton-Roberts \& Hennebry, 2012, p. 4).

Jarrah Hodge strengthens the argument for the intersectionality of race and gender in the making of the status and conditions of caregivers as she states that migrant domestic workers are primarily women, largely reflecting societal ideologies that women are responsible for the private (domestic) sphere (Hodge, 2006, p. 62). Using secondary sources with an anti-racist feminist analysis of the LCP, she focuses on the intersectional disadvantage of race and gender to demonstrate how the LCP allows the Canadian government to exploit and marginalize female live-in caregivers from minority groups (Hodge, 2006, p. 60). Hodge develops her thesis by stating that the government reaps economic benefits while upholding gendered labour inequalities, which continue to devalue domestic labour whether it is paid or unpaid (Hodge 2006). Furthermore, Hodge explores the exercise of the live-in regulation under the LCP which works to further marginalize women by overworking and isolating them to the private sphere (Hodge, 2006, p. 63).

Pierrette Hontagneu-Sotelo and Ernestine Avila extend Hodge's argument by suggesting that modern transnational motherhood of caregivers represents a continuation of the legacy of 
applying coercive systems of labour to racialized people and not recognizing their family rights (Hontagneu-Sotelo \& Avila, 1997, p. 552). They understand that motherhood is not biologically predetermined but historically constructed (Hontagneu-Sotelo \& Avila, 1997, p. 549). Women are victimized and systemically oppressed through the LCP, since women of colour domestic workers often leave a system in their source countries wherein they are responsible for the private realm of childcare and domestic work and are pushed into another system of extreme gender stratification with intersectional disadvantages of race and class (Hontagneu-Sotelo \& Avila, 1997, p. 556). Hontagneu-Sotelo and Avila argue that such migrant labour systems aim to maximize economic productivity and offer very little supports to sustain family life. Caregivers, while deprived of their own family, are expected to perform reproductive labour for their employers.

Sedef Arat-Koc (2006) expands the debate for regulatory impacts of the LCP through a careful analysis on the feminization of international labour migration and practices of 'transnational motherhood' or distant mothering. The transnationalization of social reproduction is primarily evidenced through the experiences of trans-border and transnational families where females, in this case migrant caregivers, are separated from their children and respective families. Critiquing the LCP from a feminist angle, she defines paid and unpaid forms of reproductive labour as gendered labor contained within the feminine sphere that pertains to childcare, housework, cleaning and cooking. Arat-Koc (2006) further notes that the phenomena of 'transnational motherhood' leads to countless psychological conditions including emotional distress, depression and anxieties (p. 85). Arat-Koc states that several migrant domestic workers experienced forced family separation as a form of abuse, which was emotionally scarring (permanently) (Arat-Koc, 2006, p. 87). Thus, the lived struggles and experiences of caregivers 
demonstrate the practical implications of the LCP legislation which marginalizes women based on the normative gendered identities upheld by the nation-state through law.

\section{Issues of credential recognition for internationally trained nurses}

In order to re-enter the nursing profession in Ontario, internationally trained nurses must complete the registration regulation required by the College by the Nurses of Ontario (CNO). Internationally trained nurses who migrate to Canada through the LCP can transition to nursing only after completing the LCP and the necessary hours for permanent residency. The CNO is a nursing regulatory body that protects the public interest, and sets requirements to enter the nursing profession, while establishing and enforces nursing standards in Ontario. Applicants with the $\mathrm{CNO}$ can be organized under 3 categories; internationally educated nurse (educated outside of Canada), Canadian applicants (from a different Canadian province), or nurses educated at an Ontario school of nursing. Although the registration regulation for all nursing applicants are standardized, internationally trained nurses educated outside of Canada are impacted the most. Issues of employment rights, systemic discrimination have been reported as the impacts of the LCP and the registration regulation by the CNO. These programs work to intersectionally impact women on the basis of gender, and race.

Mina D. Singh and Anne Sochan examine the impediments, which internationally trained nurses face through credentialing process. The authors provide recommendations extracted from the voices of internationally trained nurses. The recommendations work to help the credentialing process for internationally trained nurses who want to become registered nurses in Ontario. More importantly, they focus on how the credentialing processes can be made "transparent, standardized, and harmonized" between international regulatory bodies and their national immigration bodies. They state that internationally trained nurses, regardless of their pathways to 
Canada, face the same difficulties with credentialing bodies and educational bridging programs (Singh \& Sochan, 2010, p. 57).

Singh and Sochan discuss the impediments to the credentialing process by identifying three main issues. The first issue refers to transparency in the credentialing process. Although the nurses had hands on Canadian clinical practice experience through the bridging programs, they wanted their education from their source countries to be recognized. Internationally trained nurses stated that some elements of the programs made them repeat their nursing education, and provided no academic benefits (Singh \& Sochan, 2010, p. 58). The bridging programs add additional financial strain on the internationally trained nurses who have to balance education with part time work in order to pay for courses. The second issue refers to standardizing the credentialing process. Internationally trained nurses recommended the standardization of procedures in the assessment and approval of qualifications. Internationally trained nurses expressed frustration over the acceptance of nursing education for colleagues who had completed identical foreign nursing programs when they themselves were rejected for no clear reason (Singh \& Sochan, 2010, p. 59). The fourth theme refers to harmonizing processes between professional regulatory bodies and national immigration agencies. Internationally trained nurses state that there needs to be a harmonization between " apparent immigration needs and the professional regulatory body roadblocks" (Singh \& Sochan, 2010, p. 60).

Through the examination of "brain waste" and the unemployment/underemployment of internationally trained nurses, B. Kolawole expands from Singh's and Sochan's argument. She argues that there is a huge waste in human capital for internationally trained nurses who are already living in Ontario. She states that there is a "brain waste" largely stemming from these nurses being unable to practice their professions in Ontario. This results in internationally trained 
nurses being underemployed and unemployed. She argues that the integration of internationally trained nurses into the Canadian healthcare system can enhance patient care. She also notes that internationally educated nurses face several barriers in the registration procedures with the $\mathrm{CNO}$, which obstruct their integration into the Ontario healthcare system. Internationally trained nurses additionally face post-migration impediments through the financial burdens of additional education, training.

The significance of Kolawole's work she explores the ironic and intrinsic connection between the global shortage of nurses and the concept of "brain waste". Kolawole states that permanent resident and the lengthy registration procedures with the $\mathrm{CNO}$ hold the possibility that many nurses may potentially never be registered in Ontario (Kolawole, 2009, p. 188). Ontario can change its waste in human capital by increasing the registration and employment of internationally trained nurses who have lots of clinical knowledge. Internationally trained nurses often have more experience when contrasted to Ontario educated fresh graduates. Internationally trained nurses have the advantage of holding transcultural approaches to nursing, which can us provide more competent care for multicultural populations (Kolawole, 2009, p. 186). Once in the labour market, internationally trained nurses will continue to accumulate human capital though informal 'on the job training' (Kolawole, 2009, p.187).

\section{B. RESEARCH QUESTIONS}

This paper will specifically investigate the gendered nature of precarious labour for women of colour who are internationally trained nurses. More specifically, the paper will examine how regulatory practices impact the experiences of women, who migrated to Ontario as caregivers, transition to nursing. The key pieces of regulation which were examined includes part 6, division 3 of the Immigration and Refugee Protection Regulations, and the registration 
regulation by the CNO. Part 6, division 3 of the Immigration and Refugee Protection Regulations specifically refers to regulations governing the LCP which includes the processes for requirements for the program, processes for work permits, and applications for permanent residency. There were three research questions that guided the analysis:

1) How does part 6, division 3 of the Immigration and Refugee Protection Regulations, and registration regulation by the $\mathrm{CNO}$ create regulatory barriers for the transition from caregiving to nursing for highly skilled internationally trained nurses?

2) How does the regulation of part 6, division 3 of the Immigration and Refugee Protection Regulations allow for violation of the employment rights of caregivers? How does this delay the completion of the employment requirements for permanent residency in Canada?

3) Why is it difficult for internationally trained nurses who have relevant professional training, transition from private (caregiving) into public (nursing) labour market?

The Immigration and Refugee Protection Regulations that defines the eligibility for the program as well as the regulations needed to complete the program and transition to permanent residency in Canada regulate the LCP. It is then important to note that this paper is not examining the requirements for entry into the LCP program, but rather employment related regulation of the LCP for caregivers in their post-migration period. 


\section{THEORETICAL FRAMEWORK}

In order to understand how regulatory practices cause barriers to the transition from caregiving to nursing for internationally trained nurses of colour, the theoretical framework will explore gendered precariousness in the labour market. Through the use of existing feminist theory in academic literature this paper will provide an intersectional analysis of how certain groups of women are disadvantaged on the women are disadvantaged on the basis of race and gender. The paper will also analyze how regulatory practices use grounds of race and gender to disadvantage women by confining them to precarious types of employment, which are additionally gendered as they uphold women's traditional roles as caregivers. Using an intersectional analysis, this paper will demonstrate that race and gender are crucial dimension of oppression since a majority of the women who enter Canada through the LCP are women of colour, primarily Filipina and Caribbean women. Intersectional analysis will also help demonstrate the ways in which internationally trained nurses who migrate to Canada as caregivers and later attempt to enter the nursing profession are not facing the general challenges of the registration procedures with the $\mathrm{CNO}$, but that they are additionally disadvantaged on the basis of race, language and country of origin. Statistics state that the top source countries for internationally trained nurses are the Philippines, India, Nigeria, Jamaica and China (Office of the Fairness Commissioner, 2013, p. 23).

Next, a brief theoretical review on existing academic literature will be provided below in order to outline how gendered precariousness in the labour market, and noeliberalism intersect to create disadvantageous impacts for women of colour during their transition from caregiving to nursing in Ontario. The theoretical review is divided into two sections. The first section builds up an argument on the gendered and precarious nature of the women's work in Canada. The 
section examines how the division of labour subjects women to non-standard forms of temporary employment often with limited or no entitlements to regulatory protections The second section will examine how neoliberalism strengthened the gendered nature of of caregiving for women as well as intensifying women's caregiving responsibilities, thereby increasing the marginalization of women into traditional and gendered work.

\section{The stratification of gender and precarious employment}

Social science literature provides substantial documentation and discussions on the aggregate impact of the regulatory practices and the intersection of disadvantages on the basis of gender, race and immigrant status. Steven Hick (2007) examines social welfare in Canada, and states that gender based work division is largely determined by the combination of ideas, biology, culture, material condition and patriarchal family structures (p. 147). This collectively works to marginalize women of colour who migrate to Canada as caregivers. The Status of Women Canada adds to this debate by stating that unequal sharing of dependent care in the family may be the most persistent barrier to gender equality (Hick, 2007, p. 148). Based on the statement by the Status of Women, the commodification of domestic care work is highly evident in dominant labour market culture through the private sphere, through caregiving work that highlights gender inequality (Langevin, \& Belleau, 2000, p. 40).

Examining the intersectionality of precarious employment, and male/female activity ratios in the labour marker, Cynthia Cranford, Leah F. Vosko and Nancy Zukewich (2003) use data from Statistics Canada to explore precarious employment in Canada. They demonstrate the limitations of conventional statistical approaches, which measure precarious employment. Often, conventional approach narrowly focuses on the rise of 'non- standard' work. The term nonstandard work in Canada rose to popularity following a study released by the Economic Council 
of Canada, Good Jobs, Bad Jobs. This study stated that fully one-half of all new jobs created between 1980 and 1988 'differed from the traditional model of the full-time job.' Since then, insecurity has been considered "an essential aspect of the definition of non-standard work" (Cranford, Vosko, \& Zukewich, 2003, p. 2).

Cranford, Vosko, and Zukewich state that since the 1980s, the increase of non-standard work has eroded the social wage attached to the standard employment relationship (SER). Social wage and benefits attached to SER include entitlements such as Employment Insurance and minimum standards as well as employer-sponsored benefits including pensions and extended medical and dental coverage (Vosko, 2003, p. 3). The traditional form of SER is defined as fulltime (continuous) employment where the employee works under the direct supervision of one employer (Vosko \& Clark, 2009, p. 27). However, they state that the spread of 'non- standard work fails to provide a clear understanding of precarious employment in Canada.

Using Statistics Canada's Labour Force Survey and General Social Survey, the authors break down the standard/non- standard dichotomy by using exclusive forms of employment (fulltime permanent, full-time temporary, part-time permanent, and part-time temporary). Examining dimensions of precarious employment, the authors list full-time permanent as the least precarious followed by full-time temporary, then part-time permanent and part-time temporary as the most precarious (Cranford, Vosko, \& Zukewich, 2003, p. 8).

Their analysis allows for empirical analysis of which forms of employment are growing to increase labour market insecurity (Cranford, Vosko, \& Zukewich, 2003, p. 2). This in turn strengthens the conception of precarious employment Thus, these authors argue against the narrow analysis standard/non-standard employment dichotomy for measuring labour market insecurity. Rather, a new approach to understanding precarious employment examines 
employment forms in relation to dimensions of precariousness (Vosko, 2003, p. 3). Dimensions of precariousness include regulatory protection, income level and control over the labour process.

Analyzing the intersectionality of gender and precarious employment, the authors state that men are more likely than women to be employed in full-time temporary wage work. Men, therefore, are more likely to have the least precarious forms of wage work. Statistics prove that $72 \%$ of men are full-time permanent employees, while only $60 \%$ of women (Cranford, Vosko \& Zukewich, 2003, p. 14). The authors compare labour market security between women of colour and white men. Statistics suggest high levels of insecurity for women, as $10 \%$ of women of colour are in part-time temporary jobs, and $17 \%$ are in part- time permanent jobs. In stark contrast, only $7 \%$ of white men are in stuck in precarious forms of wage work (Cranford, Vosko, \& Zukewich, 2003, p. 16).

Using a new approach to measuring labour market insecurity, prescribed by Cranford, Vosko, and Zukewich (2003), Leah F. Vosko and Lisa F. Clark (2009) examine employers' choice of non- standard forms of employment, such as part-time and contract work, selfemployment, and work arrangements such as shift work and home-based work (all tied to labour market deregulation). They develop their argument on the link between precarious employment and gender in the Canadian labour market through use of four concepts; precarious employment, the standard employment relation, social reproduction, and the notion of the gender contact. Examining the relationship between precarious employment, gender, and social reproduction they state that precarious employment in the Canadian labour market is often compared to forms of 'non-standard' forms of employment, which includes temporary employment (Vosko \& Clark, 2009, p. 27). Non-standard forms of employment have been steadily increasing in Canada, 
heavily impacting women. The authors state that SER shaped, and continues to shape familial obligations, household forms, and the organization of the labour force. The "Canadian variant" of SER is heavily influenced by the design and categorization of gendered labour and social policies in Canada (Vosko \& Clark, 2009, p. 27).

Vosko and Clark (2009) remark that historically, the Canadian variant of SER was linked to gendered practices, specifically to social reproduction (p. 28). The article outlines the evolution of SER and the consequential subjugation of women in precarious employment. They state that SER was first limited to male blue-collar worker, but it also expanded to include whitecollar workers, who were also primarily men (Vosko \& Clark, 2009, p. 28). The SER functions as a model of employment, and further as a governance mechanism that additionally contributes to a gender contract. Vosko and Clark (2009) state that the gender contract, delegates men as breadwinner, while women are assigned roles of primary responsibility (largely unpaid) for caregiving (p. 27). This analysis helps explain how and why domestic work is gendered and how, even when it is paid work, it has remained precarious through temporary work permits and contracts with the employer.

Vosko and Clark's findings reveal the that women continue to represent the majority of workers in part time and temporary forms of employment, with low wages and limited access to regulatory protections (Vosko \& Clark, 2009, p. 38). This trend can also be expanded to highlight the scope of violation through regulatory practices. Although, Vosko and Clark did not make references to immigration or to migrant workers, the research finding of gendered precarious employment with limited regulatory protections can also be extended to the case of migrant workers who enter the private markets of the Canada through the LCP. 
Using data from Statistics Canada Vosko and Clark demonstrate that gendered patterns surface when temporary forms of employment by prime working age men and women are broken down by type. For example, over four times as many women, than men are in part-time permanent employment. And almost five times as many women as men worked part time and temporary jobs, and they earned less than $\$ 10$ per hours in 2007 (Vosko \& Clark, 2009, p. 33).

\section{The influence of neoliberalism on gendered precariousness}

Next, the paper examines how neoliberalism affects the gendered and the precarious status of workers in the labour market. This exploration is mandatory to the understanding of how political regimes, and dominant labour market trends work to disadvantage women in standard full time employment. Raewyn Connell (2010) uses a theoretical framework that consists of a feminist critique and discourse analysis of neoliberalism in Canada and its unequal gendered impacts on the division of rights. She states that the primary goal of neoliberalism is economic expansion, profits and the markets. Connell elaborates explaining that the economy and the state engage in the reconstruction of family and gender roles to achieve these goals (Connell, 2010, p. 26). While neoliberal theory predicts equal opportunities in the labour market regardless of race and gender, Connell disagrees. She states that neoliberalism, in practice, imposes more unpaid work on women as caregivers for the young, old and the sick (Connell, 2010, p. 27).

Catherine Kingfisher adds to Connell's argument on the negative impacts neoliberalism has on women. She argues that neoliberalism is not just an economic idea; but that it also sets social prescriptions, which deal with both the public and private sphere. Neoliberalism in conjunction with globalization is responsible for the establishment of a minimalist state, which has resulted in negative impacts on women (Kingfisher, 2002, p. 42). The neoliberal regime 
believes in deregulation of the labour market and a shift away from state responsibility for social protection guaranteed by the welfare state. According to neoliberal philosophy, social protections and its redistributive policies hinder economic growth, which works against the principles of neoliberalism (Kingfisher, 2002, p. 38). The consolidation of neoliberalism and globalization produces an increased polarization of society since men receive the well paid jobs in the public sphere, while women are stuck in the low paying jobs in a devalued sector. Internationally trained nurses who undertake paid domestic work, are then disadvantaged on multiple levels. They are disadvantaged by social constructions of gender, and also disadvantaged by the fact that they have precarious and temporary citizenship status.

\section{METHODOLOGY}

The paper draws on primary government sources, documents from the $\mathrm{CNO}$ as well as secondary academic sources to examine the impact of regulatory practices. The review of the literature (in the background to the paper and in the theoretical framework) was conducted using academic literature. In addition, this paper uses primary sources to conduct a policy analysis to analyze how 'bad' regulatory practices and regulations create impediments to successful labour market integration for internationally educated nurses, in their respective fields of professional training. Primary sources will include the Immigration and Refugee Protections Regulations, and the registration regulation by the CNO. Secondary resources will draw on insights from feminist literature. 


\section{E. SIGNIFICANCE AND ORGANIZATION OF PAPER}

\section{Significance of Paper}

The social problem presented through this paper is a significant policy issue since it outlines the contradictions, tensions and underlying problems in Canada's immigration program, newcomers' settlement experiences, as well as issues with credential recognition. This social problem continues to be a policy issue as the regulation of programs set by government bodies and registration requirements (licensing requirements) set by regulatory bodies alike, intersectionally disadvantage migrant women through exclusions to the nursing labour market. The social problem heightens when immigrant women face regulatory barriers in completing the employment requirements for the LCP in order to apply for permanent residency and open work permits in Canada. However, even when they complete these steps, additional hurdles wait for internationally trained nurses as they are unable to complete the registration requirements for registration with the College (within the time restraints) that will additionally grant them nursing licensure to practice nursing in Ontario. Thus, although these migrant women may be extended permanent residency and open work permits, they still face systemic and regulatory hurdles, which prolong and/or prevent them from entering the nursing field in Canada.

While there is a wide range of literature that analyzes the barriers that the LCP presents for the settlement and integration of caregivers within metropolitan society, there is limited knowledge and discussion on indirect pathways to the regulated nursing profession for internationally trained nurses. More specifically, there is a very limited literature examining the impact of the registration regulation by the $\mathrm{CNO}$ on former caregivers who are internationally educated nurses. In addition to contributing to an under-studied area, the focus of the paper is especially important as internationally trained nurses who take indirect pathways to nursing experience a harder transition to the nursing field. Although the LCP allows internationally 
trained nurses to attain permanent residency, it does not allow them to maintain their nursing skills through active practice. This leads to deskilling and loss of their nursing knowledge. This paper address how regulations and regulatory practices create barriers to transition from caregiving to nursing for internationally trained nurses who choose indirect pathways to the nursing in Ontario. Specific research in this area is significant in both producing knowledge about the experiences of this specific group of workers, as well as contributing to more general questions about fair access to professions.

\section{Organization of Paper}

The discussion and analysis section of this paper will be divided into two subsections: complications in the pathway to permanent residency for caregivers, and barriers to nursing licensure for internationally trained nurses. Figure 1 shows the three-step process that foreign trained nurses have to go through. The paper explains how internationally trained nurses become stuck between the steps as a result of the regulatory practices (LCP and registration regulation by the $\mathrm{CNO}$ ).

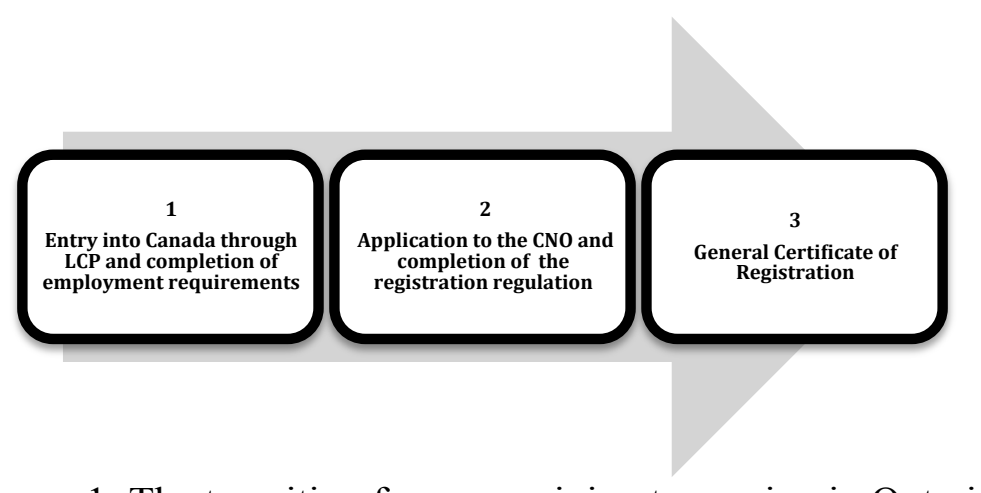

Figure 1: The transition from caregiving to nursing in Ontario

The paper will conclude with recommendations for improving regulations governing caregivers under the Live-in Caregiver Program; as well as improving regulations governing international applicants with the CNO. 


\section{F. SCOPE AND LIMITATIONS}

The scope of the paper restricts analysis to the impact of gendered and precarious labour through the regulatory practices of the LCP and registration regulation by the CNO. It is crucial to note that, the context of the analysis is restricted to internationally trained nurses and their transition from caregiving to nursing in Ontario.

It should also be noted that only a slither of the migrant caregiver population are internationally trained nurses who use the LCP as a channel through which they transition to nursing. A major limitation of the data presented through the paper that there are no figures as to the percentage of internationally trained nurse who came through the LCP. Internal government documents indicate that a very small percentage of applicants to the $\mathrm{CNO}$ who migrate to Canada through the LCP and transition to the registration processes with the CNO. Moreover, tracking down internationally trained nurses who come to Canada through the LCP as caregivers with hope to transition to nursing after the completion of the LCP is a very hard task. This is because these migrant women do not need to initially state their intent to re-enter the nursing profession during the pre-migration period (to Canada). Another limitation is that the paper does not provide a discussion of the variety of factors behind why internationally trained nurses are forced to migrate to Canada through the LCP (to re-enter the nursing profession), instead of the Federal Skilled Worker Program or other immigration streams which value human capital.

\section{G. TERMINOLOGY}

In this paper, the term 'caregiver' will refer to migrant women who work under the LCP. The term 'migrant domestic worker' and 'foreign national' will refer to a caregiver working in Canada with a temporary work visa who is a citizen of another country. The CNO is the 
regulatory body for nursing in Ontario. The term 'College' will be used to make informal reference to the CNO. The term 'international applicant' refers to one of the four groups of applicants to the CNO. 'International applicants' are nurses who are educated outside Canada who have never been registered to practice nursing in any Canadian province. The term 'permanent resident' refers to someone who has received permanent residency in Canada upon completing the employment requirements for the LCP.

Caregivers enter Canada with a temporary work permit, which caregivers must apply for after she has received a job offer from a Canadian employer (Spitzer \& Torres, 2008, p. 5). ${ }^{1}$ Once caregivers have completed the LCP, they can apply for an open work permit, which will allow caregivers to choose a new occupation. The open work permit is issued after the caregiver has completed the LCP, and applied for permanent residency (Citizenship and Immigration Canada, 2013c). Furthermore, international applicants can have authorization under the Immigration and Refugee Protection Act to stay in Canada while completing the registration requirements. $^{2}$

The term 'internationally trained nurses' refers to individuals who have completed nursing education outside of Canada. When these internationally trained want to practice nursing in Ontario, they must have a nursing license and be registered members of the CNO. Internationally trained nurses who apply to the CNO apply as international applicants. Note that being an applicant to the college is different from being a member of the CNO. Members must successfully complete the registration regulation by the CNO to receive their license to practice nursing in Ontario. When an internationally trained nurse is licensed to practice in Ontario

\footnotetext{
${ }^{1}$ If caregivers decide to extend their employment, they must apply with CIC to extend their temporary work permits before it expires.

${ }^{2}$ Former caregivers who have open work permits, but are waiting for their permanent residency to be processed have authorization under the Immigration and Refugee Protections Act.
} 
through the $\mathrm{CNO}$, a Certificate of Registration is awarded. Thus, license and registration are synonymous.

Leah Vosko (2003) defines precarious employment as a term, which is increasingly used to define labour market insecurity. She states, "In Canada, precarious employment normally involves those forms of work involving atypical employment contracts, limited social benefits and statutory entitlements, job insecurity, low job tenure, low wages and high risks of ill health (Vosko, 2003, p.1)". She elaborates stating that precarious employment is shaped by trends in capitalism (late) where employers use subcontracting and other strategies to minimize labour costs. 


\section{IMPEDIMENTS TO THE TRANSITION FROM CAREGIVING TO NURSING IN ONTARIO}

\section{H. COMPLICATIONS TO THE COMPLETION OF THE LIVE-IN CAREGIVER PROGRAM FOR CAREGIVERS}

\section{Understanding the Regulation of the Live-in Caregiver Program}

This section will outline the regulation of the LCP in order to demonstrate how 'bad' regulatory practices and systemic oppression negatively affect the completion of the LCP for caregivers. For women who migrate to Canada under the LCP, this program plays a vital role in their potential transition to nursing and settlement in Ontario. The attraction of the program that draws several caregivers to Canada has to do with the pathway to permanent residency it provides, upon the fulfillment of the employment requirements under paragraph 113(1) (d) of the Immigration and Refugee Protection Regulations. Permanent residency status, along with the attainment of an open permit provides internationally trained nurses an opportunity to remain in Canada and formally apply to the $\mathrm{CNO}$ as international applicants. Once caregivers have met the registration requirements of the $\mathrm{CNO}$, they are granted nursing licensure in Ontario. However, this "concrete" pathway to professional development is complicated through the regulatory practices of the Immigration and Refugee Protection Regulations, which governs caregivers who fall under the live-in caregiver class of the economic stream of immigration. The live-in caregiver class is defined under paragraph 110 of the Immigration and Refugee Protection Regulations (2013) as “.... class of foreign nationals who may become permanent residents on the basis of the requirements of this Division" (Division 3).

The underlying tensions within the regulatory practices of the LCP have recently come to the attention of the federal government, resulting in Regulations Amending the Immigration and Refugee Protection Regulations in 2010. The Standing Committee on Citizenship and 
Immigration also stressed the need for regulatory change in its May 2009 report, Temporary Foreign Workers and Non-status Workers. Here, they recommended that the three-year time limit to achieve the requisite work experience should be extended to four years (Immigration and Refugee Protections Regulations, 2010, p. 568). The regulations mandated amendments to key areas, which had already been highlighted by academics as problematic to the fundamental rights of caregivers. Administrative and regulatory changes sought to improve the regulatory practices of the LCP while maintaining the formal objective of the program --to respond to labour market shortages-- (Immigration and Refugee Protections Regulations, 2010, p. 569) as well as its main characteristics. The amendments include:

- An increase of 12 additional months (from 3 to 4 years) to complete the employment requirement.

- Flexibility in calculating the employment requirements of the LCP based on hours-based calculation.

- The elimination of mandatory medical examination at the permanent residency application stage. Instead, only one medical exam at the work permit application stage will be conducted with a long-term view.

The amendments to the Immigration and Refugee Protections are reflected in current legislation. Under paragraph 113(1) (d), subparagraph (i) of the Immigration and Refugee Protection Regulations (2013) caregivers are eligible for permanent residency upon completing the following requirements:

(a) they have submitted an application to remain in Canada as a permanent resident;

(b) they are a temporary resident;

(c) they hold a work permit as a live-in caregiver; 
(d) they entered Canada as a live-in caregiver and for at least two of the four years immediately following their entry or, alternatively, for at least 3,900 hours during a period of not less than 22 months in those four years,

(i) resided in a private household in Canada, and

(ii) provided child care, senior home support care or care of a disabled person in that household without supervision;

(e) they are not, and none of their family members are, the subject of an enforceable removal order or an admissibility hearing under the Act or an appeal or application for judicial review arising from such a hearing; $(f)$ they did not enter Canada as a live-in caregiver as a result of a misrepresentation concerning their education, training or experience

Reiterating paragraph 113 (d) of the Immigration and Refigee Protection Regualtions (2013), caregivers have two options to calculate their employment requirements for permanent residency in Ontario. The Immigration and Refugee Protection Regulations acknowledges that caregivers may complete the employment requirements with more than one employer or household, but this transaction cannot occur simultaneously (Immigration and Refugee Protections Regulation, 2013, Calculation, para. 2). In essence, caregivers must complete one of the following employment requirement options for permanent residency in Ontario:

- 24 months of authorized full-time employment within 4 years from the date they entered Canada under the LCP.

- 3,900 hours within a minimum of 22 months within 4 years from the date they entered Canada under the LCP. The Immigration and Refugee Protection Regulations state that the 3,900 hours cannot include more than 390 hours of overtime.

One of the four main requirements caregivers need to complete to qualify for the LCP is a written employment contract. This written contract is a private contract between the caregiver and her (future) employer, and defines the caregiver's job duties, hours of employment, salary 
and employment related benefits (Ministry of Labour, 2012, p. 1). When employers fail to comply with the terms of the written contract, a violation occurs negatively impacting the caregiver's employment standard rights.

\section{Barriers to the Completion of the Live-in Caregiver Program}

Next, the complications which arise preventing the caregivers to transition from step 1 (entry into Canada through the LCP and completion of employment requirements) to step 2 (application to $\mathrm{CNO}$ and completion of the registration regulation) will be discussed. The LCP is widely condemned as a discriminatory program, which exploits women most of whom are racialized women from developing countries. The Philippines has been a major source country for caregivers since the early 1980's (Singh, 2012, p. 23). A majority of caregivers arrive from the Philippines, followed by the Caribbean. Only a small number of white European women participate in the program (Hodge, 2006, p. 62). The Philippines currently has 460 nursing colleges, which offer Bachelor of Science in Nursing degrees (Kolawole, 2009, 186). These institutions produce competent nurses for the global labour market (Kolawole, 2009, p. 186).

Under the LCP, the intersectionality of gender, race and class works to disadvantages women of colour who migrate to Canada in hope of better professional opportunities. Domestic work appears to be historically reserved for women, as it represents underpaid and unpaid work in the private realm (Langevin \& Belleau, 2000, p. 30).

Under the LCP, migrant domestic workers experience exclusions from the benefits of the welfare state. Privilege under this context is related to social class, racial hierarchies, and most directly, to citizenship status. Langevin and Belleau (2000) state,

Bringing underpaid women from disadvantaged countries enables others in industrialized countries to free themselves from household chores, enter the labour market and achieve a certain degree of economic 
independence...the Live-in Caregiver Program therefore challenges the ideals of equality of the feminist movement. It also relegates household chores and childcare exclusively to women. (p. 38)

Unequal power hierarchies develop inequality and disadvantage along side the temporary migrant worker status, which disadvantage them on multiple levels. Disadvantage here extends from the power hierarchies and unequal power relations between the employers and employees.

In the following section, the paper will examine how the violation of the LCP contract and lack of government response cause complications to the completion of the LCP. When caregivers face problems in the completion of the program, this leads to significant delays in completing the employment requirements necessary to qualify for permanent residency in Canada (step 1), and their possibility of completion of nursing registration requirements with the $\mathrm{CNO}$ (step 2) (please refer to figure 1). The program therefore has adverse impacts on migrant domestic workers who wish to re-enter the nursing profession as it allows for unequal power hierarchies which enabling employers to exercise unprecedented amounts of power over caregivers leading to the violation of the LCP contract and related labour protections; and there is a serious lack of government response to the violation of the contracts.

\section{Unequal power hierarchies leading to violations of the Live-in Caregiver Program contract}

Separated from their families --who cannot accompany them under the regulations of the

LCP — caregivers face countless psychological problems including emotional distress, depression and anxieties (Arat-Koc, 2006, p. 87). They are additionally disadvantaged as unequal power relations, based on citizenship status, race and class, allow employers to exercise power over them resulting in their oppression, and marginalization. Under the LCP, migrant domestic workers experience exclusions from the benefits of the welfare state. The temporary status of caregivers disadvantage them on multiple levels. Disadvantage can extend from the power 
hierarchies and unequal power relations between the employers and employees through violations of the contract, and employment standard rights. Conditions of gendered precarious labour apply to migrant domestic workers through temporary contracts. Fearing the termination of their employment contracts and the vulnerability of their status in Canada caregivers withstand exploitation and oppression at the hands of their employers. Exploitation, and the violation of the contracts can take many forms.

Some of the major criticisms of the LCP address the live-in nature of the program. In addition to the completion of employment requirements, LCP expects that caregivers must reside in the private residence of their employer, without supervision. Paragraph 113(d) subparagraph (i) of the Immigration and Refugee Protections Regulations (2013) states that, caregivers must have resided in a private household in Canada," and subparagraph (ii) states that "provided child care, senior home support care or care of a disabled person in that household without supervision". The very structure of the LCP allows for the exercise of 'bad' regulatory practices. This includes the (1) live in component in the residence of the employer, (2) precarious immigration status with limited entitlements to benefits, (3) lack of government response to the violation of employment standard rights. The combination of these results in adverse impacts on caregivers, causing additional delays to the completion of the employment requirements. Cecilia Diocson, the executive director of the National Alliance of Philippine Women in Canada states that the LCP is a program that is clearly violating human rights (Singh, 2012, p. 18). Diocson argues that the live-in requirement of the program imprisons women to the homes of their employers. Diocson states that since caregivers can only conduct care work for one employer, it creates some of the conditions of indentured work for the workers (Singh, 2012, p. 19). So far the live-in requirement has not had a legal challenge even though it may very well limit the 
mobility rights of caregivers. ${ }^{3}$

The Maytree foundation also advocates for the increased protection of temporary foreign workers who are vulnerable to abuse. They maintain the argument that although temporary foreign workers have the same entitlements to employment rights and protections as other Canadians and permanent residents, they face increased vulnerability to abuse. Under this context caregivers (who cab be categorized as temporary foreign workers) face a higher vulnerability to abuse, since they often have a lack of knowledge regarding their employment rights, and the limited access to agencies and government ministries that can assist them (Maytree Foundation, 2011, p. 1). In addition, the inadequate enforcement of employment legislation and protections of caregivers' rights can also add to the vulnerability to abuse.

Under provincial labour law (Ontario), caregivers are entitled to employment standard rights that include; regular pay, recurring payday, statement of wages and deductions for pay periods (Ministry of Labour, 2012, p. 1). Under employment standard rights, caregivers cannot be required to work more than 48 hours a week; unless the employers have the caregiver's written agreement and approval form the Ministry of Labour. Caregivers are additionally entitled to overtime pay (overtime pay after 44 hours), and minimum wage $(\$ 10.25)$ (Ministry of Labour, 2012, p. 2). The unequal power relations embedded within the LCP allow employers to arbitrarily exercise their power, by denying caregivers the entitlements and protections of employment standards legislation. Additional types of violation of caregivers' rights include the termination/suspension of employment, reduction or withholding of the salary, punishing the

\footnotetext{
${ }^{3}$ Section 6 of the Canadian Charter of Rights and Freedoms restricts the mobility rights of migrant workers/caregivers (Constitution Act, 2013). This charter right is only guaranteed for Canadian citizens and permanent residents. Since caregivers' mobility rights are both restricted by the lack of entitlement to Charter rights and their work permits, they are forced to remain in the homes of their employers while completing the LCP.
} 
caregiver (emotionally, sexually, physically), or threatening the caregiver (Ministry of Labour, 2012, p. 2).

While physical, verbal and sexual violence represent the most blatant forms of abuse against migrant workers, there are also more subtle violations of the LCP contract. For instance, the provincial labour legislation does not distinguish between hours worked and hours of availability for caregivers. Since caregivers are expected to live-in and work in their employers homes, they can easily be forced to work more than the limited hours for employment standard rights without a written agreement and approval from the Ministry of Labour (Langevin \& Belleau, 2000, p. 15). Technically, caregivers can file a claim with the Employment Standards information Centre if they believe that their employer has punished them for asking about or exercising their rights (outlined in the contract and provincial labour legislation protecting caregivers) at work. If employers are found guilty caregivers may be entitled to compensation for wages owed. In practice, however, very few caregivers go this route as changing employers as a result of violations of the employment standards would be seen to further delay the completion of the employment hours required for permanent residency.

Caregivers changing employers must request documents from their former employer, a record of employment, which includes a record of overtime hours worked. The record of employment serves as evidence of working towards the completion of employment requirements needed to apply for permanent residency status and open work permits. Caregivers may run into complications when employers do not cooperate and legally comply with providing the record of employment.

Temporary work permits require that caregivers must apply for a new work permit at least 30 days before the expiry date of their work permit. Furthermore, caregivers can only work 
for the employer whose name is listed on their work permit. The status of caregivers with expired work permits changes to undocumented status (Citizenship and Immigration Canada, 2013a).

\section{Lack of government response to the violation of employment standards}

When employers don't arbitrarily exercise power over the caregivers and respect the terms and conditions of the LCP contract, caregivers are more easily able to transition to permanent residency and open work permits. Caregivers who are successful in completing the employment requirements in a timely fashion have a $98 \%$ (plus) success rate for permanent residency. Commenting on the application process the Canadian Gazette (2010) stated that 98\% of former caregivers are successful in attaining permanent residency, upon completing the LCP (p. 568).

While good working conditions often guarantee caregivers' success in getting permanent status in Canada, unfavourable relations with employers often create huge obstacles. 'Bad' regulatory practices and neglect by the government plays an important part in this. 'Bad" regulatory practices may indirectly be related to the federal and provincial inter-jurisdictional issues relating to labour regulations governing migrant workers (Spitzer \& Torres, 2008, p. 15). Caregivers working within the private homes of their employers are left without adequate legal protections since immigration is (primarily) a federal responsibility, while labour legislation (and regulation) is a provincial responsibility.

The federal government plays a large role in the LCP. The LCP is a stream of the TFWP, which assists employers with their labour needs when qualified Canadians and permanent residents are not available (Immigration and Refugee Protections Regulations, 2010, p. 568). It is interesting to note that the TFWP is jointly managed by CIC and Human Resources and Skills 
Development Canada (HRSDC)/Service Canada (Sutherland, 2008). This intricate matrix (HRSDC and Service Canada) reviews employer applications for foreign workers and issue an opinion on the likely impact on the Canadian labour market, known as a Labour Market Opinion (LMO). The LMO letter states whether the caregiver will have a positive, neutral, or negative impact on the Canadian labour market. CIC completes the process by reviewing applications from foreign workers and issue work permits (Immigration and Refugee Protections Regulation, 2013, p. 2023). To make this matrix more complex, the TFWP is administered under the authorities of the Immigration and Refugee Protection Act and the Immigration and Refugee Protection Regulations. The collective combination of governmental bodies regulating the LCP, and the lack of governmental supervision under private LCP contracts presents a large scope for the violation of caregivers' rights when employers do not meet the terms of the written contract. Furthermore, HRSDC takes precautionary steps to ensure that LMOs are only provided upon thorough investigation. HRSDC assesses the legitimacy of the job offer, and the employer's history of compliance with program requirements before a LMO is issued. Although HRSDC assesses the consistency of the wage offered to the caregiver with the prevailing wage rate for the occupation, checks whether the conditions are compatible with generally acceptable working conditions that meet Canadian standards, the legislation and existing regulations do not mandate necessary supervision.

The structure of the LCP enables the possibility of exploitation, abuse and oppression of caregivers in the private realm. Thus, although the government is not the direct oppressor, the division of government responsibilities between federal and provincial levels complicate the regulation of the LCP, which in turn creates the grounds for violation of fundamental rights. For instance, the federal government strongly recommends that employers and the caregivers enter 
into a contract. When cases of non-compliance with the enforcement of the contract come to the fore, however, the federal government cannot intervene since working conditions fall under provincial jurisdiction/responsibility (Langevin \& Belleau, 2000, p. 14). The Ontario Ministry of Labour states that caregivers working in Ontario are protected by employment standards rights under the Employment Standards Act and Employment Protection for Foreign Nationals Act. The provincial government can only intervene if a caregiver files a claim with the Employment Standards Information Centre (Ministry of Labour, 2012, p. 2). The problem additionally lies with Ontario's Employment Standards Act, which is more than 40 years old. The original design never incorporated the specifically challenging working conditions related to the live-in status of caregivers (Monsebraaten, 2011, para. 23).

Another example of complications to regulation has to do with the mandatory live-in residency requirements, which the federal government requires under LCP legislation. However, the provincial government does not have legislation which distinguishes the hours worked and the caregiver's hours of availability. This raises questions of whether employers record working hours correctly. If employers do not pay caregivers for the complete number of hours worked which may include overtime, this can lead to significant delays in the collection of the employment requirements for permanent residency in Canada.

In Spring of 2012, the Minister of Citizenship and Immigration held the Expert Roundtable on Immigration where it collaborated with leading immigration experts to examine Ontario's rapidly developing immigration issues. The discussions and conclusions of this roundtable were released in the report, Expanding Our Routes To Success: The Final Report By Ontario's Expert Roundtable On Immigration. The report stated that Ontario should design an immigration strategy to achieve immigration related goals. This was of vital importance since 
Ontario, a province that was home to many immigrants and migrant workers, has never had an immigration strategy. One of the goals the report listed was for Ontario to attract, retain, and integrate more immigrants, especially those with high levels of human capital. The roundtable produced 32 recommendations through its report Ministry of Citizenship and Immigration, 2012b, p. 3). Through the report Expanding Our Routes to Success, the Ministry of Citizenship and Immigration argues that temporary foreign workers should have increased protection in order to eliminate abuse and unsafe working conditions (recommendation 16). The report recognizes that there have been some problems with the regulation of the LCP, however it is still widely deemed a success. The report advises that the federal government should continue to strengthen the program (recommendation 18) (Ministry of Citizenship and Immigration, 2012b, p. 4). The program should be modified to grant caregivers access to settlement services upon arrival, along with faster routes to permanent residency and family reunification. The report also urges the federal government to give consideration to the mandatory live-in requirement of the program, and provide options, which could better meet the needs of both caregivers and their employers (Ministry of Citizenship and Immigration, 2012b, p. 33).

\section{International comparisons of migrant caregiving}

In comparison to the United States and England, Canada has a comprehensive LCP program with accompanying regulatory practices. For instance, caregivers who enter the American system can only hold temporary status and they are not granted a pathway to permanent residency. Similarly, caregivers in the British system do not have work permits, and are neither are they covered by immigration rules, exposing them to abuse as they lack legal status in the country (Langevin \& Belleau, 2000, p. 35). Increasing the scope for violation, British caregivers can only become citizens if they work for the same employers for four years. 
As a result of these comparisons, the Globe and Mail editorial (2012) commends the LCP as an ethical program, which should act as a superior model for international governments to follow.

Many countries that host foreign domestic workers - including Hong Kong, Israel and other nations in Europe and the Middle East - do not permit them to become citizens. They are paid a pittance and stay for years as temporary guest workers; even their children born there have no right to citizenship. Under Canada's innovative model, foreign caregivers (who must have a high school diploma, English fluency and work experience) are "fast-tracked" and can apply for permanent-resident status after completing 24 months of employment. (p. 10A)

Although the Canadian model is seen and presented by some as a towering model, we have seen how the regulatory practices of the LCP create a large scope for violation of fundamental human and employment rights.

\section{BARRIERS TO NURSING LICENSURE FOR INTERNATIONALLY TRAINED NURSES}

\section{Understanding the Registration Regulation by the College of Nurses of Ontario}

Vosko and Clark (2009) examined the gendered distribution of different forms of employment across industries and occupations in the primary working age to contextualize dominant labour market trends and patterns relating to precarious employment. Research indicated that women dominate healthcare and social assistance fields. These were the most common fields of employment for prime working age women (except part time temporary). It is then interesting to note that internationally trained nurses transition from private forms of caregiving through the LCP, to public forms of caregiving through nursing in the Canadian health care sector.

When an internationally trained nurse wishes to attain a Certificate of Registration enabling her to practice nursing in Ontario, she must complete a set of registration requirements that the College labels registration regulation (College of Nurses of Ontario, 2013c, Registration 
requirements for RNs and RPNs, para. 1). To become a registered nurse or registered practical nurse in Ontario, internationally trained and Canadian trained nurses must equally be a member of the CNO, and hold a Certificate of Registration (under one of the four classes) (Health Force Ontario, 2013, Entry to practice requirements, para. 1). ${ }^{4}$ To practice nursing in Ontario, internationally educated nurses must hold a valid General Certificate of Registration with the CNO. This will allow them to practice nursing in Ontario. The College maintains the primary role for regulating the profession of nursing in Ontario under the Regulated Health Professions Act, and the Nursing Act (Office of the Fairness Commissioner, 2008, p. 3). The College claims that its requirements seeks to ensure that the internationally trained nurses skills, and competencies are equal to Canadian educated nurses entering nursing practice in Ontario. The CNO received over $30 \%$ of new registration applications from internationally trained nurses, while only $12 \%$ new registered members were internationally trained nurses (Walton-Roberts \& Hennebry, 2012, p. 12).

There have been several studies, which examine the course of exclusion of internationally trained nurses in Ontario's public health sector. One such study, estimated that $40 \%$ of internationally trained nurses who apply to the College do not complete the registration process (Baumann, Blythe, McIntosh, \& Rheaume, 2009, p. 7). The study does not provide a clear explanation of why this happens, but it does states that internationally trained nurses suffer several impediments in obtaining their professional license, which often stop them from entering the workforce. This is an astounding figure in comparison to only $2 \%$ of Ontario educated nurse applicants who never complete the application (Kolawole, 2009, p. 187). In addition, the study

\footnotetext{
${ }^{4}$ For more information on registration classes please visit http://www.cno.org/become-anurse/about-registration/types-of-registration/.
} 
showed that $90 \%$ of registered nurses educated in Ontario, receive their Certificates of Registration within a span of 12 months (Owen \& Lowe, 2008, p. 30).

Upon review of member and stakeholder feedback on proposed regulatory changes to the registration process, the College's council approved amendments to the registration regulation in late 2010. ${ }^{5}$ Pursuant to the approval of the Ministry of Health and Long-Term Care, the amended registration regulation was reintroduced in January of 2013 with barriers "entrenched" for internationally trained nurses. The significance of the changes to the registration regulation are embedded in the purpose and goal of the regulation. The registration regulation provides the requirements for entry to practice for current applicants, active membership for registered members, and for reinstatement for all college members (Office of the Fairness Commissioner, 2008, p. 5). Thus, the amendments to the College's registration regulation not only impact new applicants, but also applicants are already in the system and have filed an application with the College.

On January 1, 2013, the proposed amendments that the College's council had previously approved in 2010 were legally amended. These amendments to the registration regulation had the largest impact on internationally trained nurses, who expressed concern over the transparency of the new registration regulation, and communication between the College and internationally trained nurses. In the following, this paper will examine the new amendments adversely impacting current international applicants (with the College). It is important to understand that international applicants (as well as all other applicants) can apply to practice nursing in two different categories, registered nurse or registered practical nurse (Health Force Ontario, 2013, Entry to Practice Requirements, para. 2).

\footnotetext{
${ }^{5}$ The 2010 proposed amendments were legally amended in 2013, and are the current registration regulation of the CNO.
} 
It is important to understand that although the registration requirements are the same for Ontario educated applicants and internationally trained applicants; the registration requirements impact internationally trained nurses more. ${ }^{6}$ The registration requirements that cause immediate barriers to nursing licensure for internationally trained nurses include the completion of a recognized nursing program. Internationally trained nurses are often asked to take the Objective Structured Clinical Examination, if their nursing program is not recognized (College of Nurses of Ontario, 2013b, Objective Structured Clinical Examination, para. 3). If educational gaps are identified through the Objective Structured Clinical Examination, internationally trained nurses may be asked to take additional courses, which often result in the full enrollment in a bridging program. Bridging programs present large financial costs for nurses and can often prove to be pointless knowledge, which the internationally educated nurses already know. Internationally applicants have also complained about poor and slow communications from the College. A detailed analysis of the specific requirements which impact internationally trained nurses will be discussed in the section, barriers to nursing licensure. The following examination of the current registration requirements is outlined by old requirements (which did not change on January $1^{\text {st }}$, 2013), new requirements (which were introduced on January $1^{\text {st }}, 2013$ ), and amended requirements (which were amended on January $1^{\text {st }}, 2013$ ).

\section{Old requirement: Completion of a recognized nursing program}

First applicants are expected to have completed a nursing program from a recognized university or college in their country of nursing training. Registered nurse applicants must hold a baccalaureate degree from an approved Ontario nursing program or an equivalent (Office of the Fairness Commissioner, 2008, p. 4). If the college determines that the applicant holds a degree or

\footnotetext{
${ }^{6}$ The reasons as to why internationally trained nurses/international applicants are impacted more than Ontario educated applicants are discussed in the section, barriers to nursing licensure.
} 
diploma equivalent to, or has the competencies required for the degree, applicants are eligible to write the registration exams.

Registered practical nurse applicants require a diploma from an approved Ontario practical nursing program or an equivalent. However, if the College determines that the applicant's program does not meet the program requirement, the applicant will be asked to complete an Objective Structured Clinical Examination in order to proceed further with the application (College of Nurses of Ontario, 2013b, Objectively Structured Clinical Examination, para. 4). The application can only be practiced once an applicant has demonstrated entry-topractice competencies through the Objective Structured Clinical Examination. However, applicants may be asked to complete additional education in Ontario if the College determines that the applicant has not completed an approved nursing program (College of Nurses of Ontario, 2013b, Objectively Structured Clinical Examination, para. 4).

\section{Old requirement: registration examination}

Applicants are also asked to write the registration examination, which can only be written at designated testing sites within Canada (College of Nurses of Ontario, 2013a, Complete the registration examination, para. 2). Registered nurse applicants must write the Canadian Registered Nurse Examination; and registered practical nurse applicants write the Canadian Practical Nurse Registration Examination conducted by the Canadian Nurses Association (Owen \& Lowe, 2008, p. 32).

\section{New requirement: jurisprudence examination}

The College introduced the jurisprudence examination, also known as the entry-topractice in January of 2013, following the amendments to the Registration Regulation. Here 
applicants are asked to complete an online exam, which assesses their awareness and understanding of the legislative and regulatory framework that governs the nursing profession in Ontario (College of Nurses of Ontario, 2013c, Complete the jurisprudence examination, para. $1)^{7}$

\section{Amended requirement: evidence of nursing practice}

The next amendment to the registration regulation is on the evidence of practice, which has been reduced from 5 years to 3 years (College of Nurses of Ontario, 2013c, Provide evidence of practice, para. 1). Evidence of practice can be demonstrated in three different ways. First, applicants can complete a nursing program for the category to which they are applying for (College of Nurses of Ontario, 2013c, Provide evidence of practice, para. 2). The second choice allows applicants to demonstrate safe practice through experience as a registered nurse or a registered practical nurse (College of Nurses of Ontario, 2013c, Provide evidence of practice, para. 3). ${ }^{8}$ This experience does not need to be in Canada; it can be from the applicant's country of training. Under the second option, applicants must get a reference from the most recent employer verifying that they have worked in the nursing field within the past 3 years (Office of the Fairness Commissioner, 2008, p. 10). The third option offered by the College, refers to the completion of additional training, experience, examinations or assessments within a time frame specified by the College (College of Nurses of Ontario, 2013c, Provide evidence of practice, para. 3). There is a lack of transparency on the time frame specified by the College for applicants.

\footnotetext{
${ }^{7}$ Awareness and knowledge on legislative and regulatory framework for the jurisprudence examination includes law, regulations, and College by-laws, practice standards and guidelines. ${ }^{8}$ Applicants must demonstrate past nursing practice, relevant to the category that they are applying to (can be foreign experience).
} 


\section{Amended requirement: language proficiency in either English or French}

Under the new amendments, applicants must also demonstrate a higher benchmark, from

the previous requirements, for language proficiency in either English or French. Communication and comprehension are the core of language proficiency, which include oral and writing proficiency. For the purposes of this paper, only English examinations for language proficiency, International English Language Testing System will be examined (College of Nurses of Ontario, 2013a, Accepted language proficiency tests, para. 2).

First, Internationally educated nurses can demonstrate their language proficiency by scoring the required minimum benchmark scores on one of the language proficiency tests approved by the Registration Committee (College of Nurses, 2013a). International applicants must demonstrate language proficiency within two years before they are issued a certificate of registration.

The second option to demonstrate language proficiency is through the completion of a nursing program in any Canadian jurisdiction. In order for a nursing program to qualify, the primary language instruction for theory and clinical portion of the program (as well as the institution) (College of Nurses of Ontario, 2013c, Demonstrate language proficiency in either English or French, para. 2), must be English or French. The College is specific in stating that it will not accept demonstration of language proficiency through an online or distance education program. International applicants can also demonstrate language proficiency through documenting evidence of practice as a registered nurse or registered practical nurse in a setting where service was provided in English or French. The College additionally requests that the primary language of the clients and the setting where practice took place was English or French. Language requirements do no effect all international nurses in the same way. Nurses who were educated in commonwealth countries such as France, United States of America, United 
Kingdom, and Australia have a higher likeliness to score higher in the language examinations.

This analysis proves that international applicants from developing nations are disadvantaged on the basis of race and country of origin. This can also act as crucial factors resulting in major delays to the completion of the registration requirements.

\section{Amended Requirement: proof of citizenship, permanent residency or authorization under the Immigration and Refugee Protection Act}

Applicants must also provide proof of Canadian citizen, permanent residency (in Canada), or hold authorization under the Immigration and Refugee Protection Act in order to practice nursing in Ontario. Authorization under the Immigration and Refugee Protection Act would refer to a work permit that provides authorization to practice nursing in Ontario (College of Nurses of Ontario, 2013c).

\section{Amended Requirement: declaration of registration requirements}

Applications must also complete the declaration of registration requirements to become registered members of the College. The declaration of registration requirements refers to declarations of good character (demonstrated in profession), an applicant's suitability to practice, and a summary of the applicant's Canadian criminal record (College of Nurses of Ontario, 2013c, Complete a Declaration of Registration Requirements, para. 3). ${ }^{9}$ The amendments also introduced an expansion in self-reporting, and an expansion in conduct and character requirements (College of Nurses of Ontario, 2013c, Complete a Declaration of Registration Requirements, para. 3). The expansion of self-reporting demands that applicants must notify the College of their involvement with any proceeding held by a regulatory body that regulates a

\footnotetext{
${ }^{9}$ For more information please visit www.cno.org/en/become-a-nurse/newapplicants1/declaration-of-registration-requirements/.
} 
profession (applies to professions regulated by healthcare and non-healthcare regulatory bodies) in any province (Czerniawski, 2013).

Adding additional barriers to the completion of the registration requirements, the College expects applicants to complete their application within a 2-year time limit (from the day an application is filed). However, the application will be extended if the applicant is completing additional training and education in Ontario. International applicants have raised concern over the lack of access to information and communication from the College.

\section{Barriers to Nursing Licensure}

Next, this section will explore the complications that arise for internationally trained nurses to transition from step 2 (application to $\mathrm{CNO}$ and completion of the Registration Regulation) to step 3 (General Certificate of Registration). In addition to the structural and (potential) regulatory challenges under the LCP, internationally trained nurses face additional barriers in transition to nursing under the current registration regulation by the CNO. More specifically, internationally trained nurses who take indirect pathways to the nursing profession

have reported increasing difficulties to the completion of the registration requirements after the amendments to the registration regulation by the CNO. The nature of the systemic exclusion of internationally trained nurses is imbedded in the registration procedures of the CNO. Even before the added barriers that the new amendments to the registration regulation have been put into place, international applicants faced longer processing times, and the burdens of taking additional courses. In 2004, there were 1992 internationally trained registered nurse applicants to 
the $\mathrm{CNO} .{ }^{10}$ Evidencing barriers and impediments to internationally trained nurses, statistics prove that $94.9 \%$ (1843) were unable to complete the registration process within a year of application (Kolawole, 2009, p. 185). Thus, only 5.1\% of Ontario internationally educated registered nurse applicants completed the application process within one year. In stark comparison $82.5 \%$ of Ontario educated applicants became registered in under a year (Kolawoke, 2009, p. 185). ${ }^{11}$

Labour market exclusion of internationally trained nurses has become very apparent through the new amendments. This is consistent with the findings of academic literature outlining impediments to labour market inclusion of foreign trained professionals. The Conference Board of Canada reports that skilled visible minority immigrants face numerous barriers to employment (Schalm \& Guan, 2009, p. 23). This is also the case with internationally trained nurses who enter Canada in hopes of re-entering the nursing profession. Intersectional analysis provides an understanding of how gender, race, and immigration status collectively create a system of oppression and discrimination which works to marginalize internationally educated nurses. Racial and systemic discrimination exists as major factors leading to the devaluation of foreign credentials (Schalm \& Guan, 2009, p. 25). It is hard to argue ignore the racial element leading to the declining economic performance of some groups in the labour market. In this case, the decline in performance can be (at least) partially attributed to the increasing barriers internationally trained nurses face when completing the registration requirements for nursing licensure.

\footnotetext{
${ }^{10}$ The number of international applicants to the $\mathrm{CNO}$ changes every year, and studies conducted on internationally trained nurses often do not provide specific data on the percentage of internationally trained nurses who migrate to Canada as caregivers (through the LCP). ${ }^{11}$ The argument can be made that even though it applies the same onerous requirements on Canadian nurses coming from other provinces, the $\mathrm{CNO}$ pushes them through the credentialing and licensing processes in a faster and fairer manner.
} 
Applicants face barriers in registration procedures as they experience longer wait times in the collection of documents from their respective foreign countries of training; in completing additional assessments or exams; bridging education gaps, to demonstrate that they are competent for safe nursing practice in Ontario (Zubeida Ramji, personal communication, August 12, 2013). In the province of Ontario, it has been largely evidenced that the CNO exercises professional protectionism, favouring Ontario-trained nurses before internationally trained nurses (Schalm \& guan, 2009, p. 24). This has inevitably led to labour shortages in Ontario. Current international applicants to the $\mathrm{CNO}$ experience several barriers, which delay the completion of the registration requirements, deterring them from the pursuit of attempts to enter Ontario's healthcare labour market.

In 2010, the honorable minister of state Steven Fletcher has stated that, Through Canada's Economic Action Plan, we are working with partners to develop a common approach to foreign credential recognition. These projects contribute to a fair, efficient and timely system that will help internationally trained nurses find work in communities across Canada. (Employment and Social Development Canada, 2010, para. 8)

The 2013 amendments to the registration regulation were introduced as a means to harmonize national registration requirements for internationally trained nurses, including language standards (Employment and Social Development Canada, 2010). Contrary to the statement by Minister Fletcher, however, the new amendments to the registration regulation did not contribute to fair, effective and a timely for internationally trained nurses. They rather created the opposite impact. As explained below, internationally trained nurses experienced the amendments as lacking in clarity, unfair, and inappropriate in their timing. They also said that they were administered with poor communication and guidance from the College. The Conference Board of Canada noted 
that the underutilization of the skills of internationally trained professionals has resulted in a 3.4 to 5 billion dollars loss in productivity (Ministry of Citizenship and Immigration, 2012a, p. 5).

Racialized international applicants, mainly women looking to conduct care work through nursing, are doubly disadvantaged by a second set of additional systemic and regulatory barriers while being already oppressed on the margins of racial difference. The Philippines has remained the top source country for internationally trained nurses from 2008 to 2011 followed by India. In 2011, the top five source countries for immigrant nurses were (1) Philippines, (2) India, (3) Nigeria, (4) Jamaica, and (5) China (Office of the Fairness commissioner, 2012, p. 54). The amendments to the evidence of practice, and the introduction of the new Objective Structured Clinical Examination present major barriers blocking labour market access to internationally trained nurses. It is significant to note that even though the requirements for all internationally trained nurses appear to be the same, internationally trained nurses who transition to the nursing profession from the LCP face additional time restraints (will be explored further). Statistics Canada compared 2006 employment rates Canadian-born and internationally educated professions who were working in professions (all regulated professions, not only nursing) for which they were trained in; statics show that 62 percent of the Canadian-born were working in regulated profession. This figure is contrasted with only 24 percent of internationally trained who were actively working in the regulated professions (Ministry of Citizenship and Immigration, 2012a, p. 11). The statistics are indicative of the barriers to employment for internationally trained professionals in their post-migration period.

\section{Barriers to registration caused by the administration of the College}

It is not just the regulations but also the administration of the $\mathrm{CNO}$ by the College that presents problems. The College provides poor communication, with prolonged time delays and 
responses. Communication between the College and current applicants informating applicants of the new ammendments to the registration regulation were sent out too late. This caused delays for applicants in compiling necessary documents and completing required exams. Applicants received letters as a late as Fall of 2012, preventing applicants from completing any outstanding registration requirements required for the Certificate of Registration (Zubeida Ramji, personal communication, August 12, 2013). This meant that applicants who could not complete the outstanding registration requirements prior to January $1^{\text {st }} 2013$ would be subject to the newly amended requirements. This meant reassessment of examinations and credentials which international applicants may have already sucessfully completed prior to the legal enforcement of the new ammendments. Applicants additionally complained that letters of correspondence from the College lacked clarity and personal specificity in accordance with each individual application. Applicants also expressed frustration over the complex and often convoluted language used throughout the letters. Many applicants criticized the information displayed on the College's website (Zubeida Ramji, personal communication, August 12, 2013). The timelines provided for the assessment/registration process were not reasonable or transparent as they did address the experiences of internal applicants who had waited over a year for their assessment results.

\section{Barriers to registration caused by the amendments to the registration regulation}

The first set of barriers is related to the requirements for completion of a recognized nursing program. The credential assessment process for internationally trained nurses is different from that of Canadian trained nurses, when it comes to the acceptance of nursing education completed outside of Canada. Applicants who have a unique educational program, which has not previously been assessed by $\mathrm{CNO}$, are assessed by World Education Services. This third party 
organization is then responsible for determining and assessing the education level equivalency (Office of the Fairness Commissioner, 2008, p.8). A longitudinal survey on immigrants to Canada conducted by Statistics Canada, indicate that 35.4 percent of internationally trained professionals blame their employment difficulties on the lack of foreign credential not being recognized (Schalm \& Guan, 2009, p.23). Adding to the array of frustration with the College, internationally trained nurses and current applicants to the CNO are increasingly discontent with CNO's non-standardized credential assessments for international applicants who have identical nursing (foreign) educations. A former applicant states,

I think they don't have standards, because it depends on the [regulatory body] consultant. I have some friends ... They have the same BScN degree and they were assessed differently ... They were asking me 'how is your assessment different from us, and our requirement is the same'? . . . Some of my classmates [from the Philippines] are already RNs. (Mina and Sochan, 2010, p. 59)

The non-standardized nature of the College's assessment process leads to questions about the validity and skill level of the third party assessors. The inconsistencies of the assessment process lead to inequalities, and create additional impediments for internationally trained nurses to complete the registration requirements.

If the College determines that the applicant's program does not meet the nursing program standards, the applicants will have to take the Objective Structured Clinical Examination (College of Nurses of Ontario, 2013b, Objective Structured Clinical Examination, para. 4). The Objective Structured Clinical Examination is offered through a third party assessor, the Centre for the Evaluation of Health Professionals Educated Abroad (Office of the Fairness Commissioner, 2008, p. 13). Internationally trained nurses have reported instances where the nursing programs from their respective countries of training do not meet the College's program requirements. As the applicants can only take the Objective Structured Clinical Examination 
once, they often take the financial burden of full enrollment in a bridging program to fill the education gaps identified by the assessment(s) (Mina \& Sochan, 2010, p 59). The bridging programs add serious financial strain to the registration process. A former international applicant to the $\mathrm{CNO}$ expressed her frustrations over the financial costs associated with taking additional education through bridging programs. She states,

Okay. I already have, I think, 7 courses, 6 to 7 courses, and we paid it in cash. And then my husband asked his brother to send him $\$ 1500$ so that our bank will not go negative. His brother in the USA sent $\$ 1500$ a month ago to pay for my other course, and that helped a lot. So this time we paid through credit card. (Mina \& Sochan, 2010, p 59)

Internationally trained nurses who are identified as having education gaps are directed to enroll in the full bridging program, instead of completing individual courses necessary to fill the education gaps (Mina \& Sochan, 2010, p. 59). In addition, although language proficiency can be met through the successful completion of a bridging program in Ontario, there are no guarantees that the College's Registration Committee will accept this alternative as sufficient (Zubeida Ramji, personal communication, August 12, 2013).

The second set of barriers is related to changes in the evidence of practice, which has been reduced from a 5 to a 3-year period. International applicants who are able to demonstrate evidence of practice within 3 years are considered to hold "safe practice" (College of Nurses of Ontario, Provide evidence of nursing practice, para. 1). Applicants, on the other hand, who cannot demonstrate safe practice are deemed "unsafe to practice" and must take bridging programs to update their clinical practice. The Office of the Fairness Commissioner (OFC) notes that every year an internationally trained profession is out of practice, he/she is less likely to succeed in joining the professional labour market (Office of the Fairness Commissioner, 2012, p. 52). 
Discussion among internationally trained nurses indicated that former applicants who were impacted by the 2005 amendments to the registration regulation, were grandfathered (Zubeida Ramji, personal communication, August 12, 2013). The College has previously changed its education requirements for registration regulation in 2005. The lack of grandfathering provisions in the post-amendment period has left internationally trained nurses and their respective families with emotional, psychological, and financial burdens (Zubeida Ramji, personal communication, August 12, 2013). Internationally trained nurses demanded that they should be grandfathered and allowed to receive their Certificate of Registration allowing them to practice nursing in Ontario. Several applicants raised concern over the slow processing times for the application. One current applicant stated that as a result of slow processing times, which take over a year, some applicants missed the 3-year window of safe practice (Zubeida Ramji, personal communication, August 12, 2013).

The change in evidence of practice requirements systemically oppresses nurses of colour who take indirect pathways to nursing. If internationally trained nurses complete LCP's 3,900hour option within a minimum of 22 months, they will have roughly about 2 years left in previous evidence of practice. Given the potential employment problems and change in employers, caregivers are more than likely to extend the completion of the employment requirements beyond the 22 months. However, caregivers who decide to complete their employment requirements over a span of 3 to 4 years risk "unsafe practice" (since they cannot demonstrate evidence of practice within 3 years). The OFC confirms that the complexity, length (of time) and financial cost associated with the registration process are some of the most significant licensing barriers for internationally trained professionals (Office of the Fairness Commissioner, 2012, p. 38). 


\section{Unionization and protection of interests}

Ontario has several nursing associations such as the Registered Nurses Association of Ontario, the Registered Practical Nurses Association of Ontario, and the Ontario Nurses Association, which protect their members. All members of these unions are registered members of the CNO. However, international applicants are disadvantaged by slow assessment processes and often get the "short end of the straw" since they have limited access to organizations which focus on applicant success to integration with the labour market. An organization, which emphasizes internationally trained applicant success, is CARE (Creating Access to Regulated Employment) Centre for Internationally Trained Nurses. CARE recognizes the challenges for internationally educated nurses who are unable to practice their profession as a result of the regulatory barriers set through the registration requirements. CARE has provided and continues to provide courses and support services for internationally trained nurses to double the success rates for examinations (CARE, 2013). CARE has been a crucial player in the successful integration of over 1,000 internationally trained nurses who currently work in the healthcare system in Ontario. The mobilization of organizations protecting internationally trained nurses must increase to successfully allow qualified professions the right to practice their professions. 


\section{RECOMMENDATIONS}

\section{J. THE URGENCY TO END 'BAD' REGULATORY PRACTICES AND SYSTEMIC OPPRESSION}

The province of Ontario is looking to recruit more economic immigrants who are ready to step into skilled jobs in order to eliminate predicted future labour shortages. The Ontario government only has jurisdiction to change employment legislation and regulations, but lack jurisdiction to change immigration status and regulations for migrant caregivers. It is, however, in a position to recognize the structural and procedural barriers to licensing which internationally trained nurses experience (Ministry of Citizenship and Immigration, 2012a, p. 11). The province should take into consideration the number of internationally trained nurses who take indirect pathways to the nursing profession. Both the federal and provincial governments of Canada need to also incorporate highly skilled nurses who indirectly enter Canada (through TFWP, such as the LCP) into their immigration strategy. The certification and employment of highly educated and experienced internationally educated nurses benefit the Ontario health system by up addressing shortages in nursing. There have been numerous changes in the health care system and healthcare labour market, which continue to impact the supply of nurses and the demand for nursing care. One such change is the increased demand for nurses in specialty areas such as critical care, trauma, emergency, neonatology and the operating room (Office of the Fairness Commissioner, 2008, p. 10).

Several barriers, challenges and complications have been identified in the transition from caregiving to nursing in Ontario. The analysis of two very programs -the LCP nursing registration regulation-- provided in this paper demand that dominant regulatory policies in both fields must be amended. The recommendations made in the subsequent section are formulated to 
provide the most practical short-term solutions for the problems faced by internationally trained nurses who transition from private caregiving work to public caregiving work. These recommendations aim to remove the bar that divides entitlements based on immigrant vs. citizenship status; and to improve fairness and equality in the Canadian labour market.

\section{K. RECOMMENDATIONS TO IMPROVE REGULATIONS GOVERNING CAREGIVIERS UNDER THE LIVE-IN CAREGIVER PROGRAM}

In order to address the treatment of temporary foreign workers the government has also introduced a 2-year ban (in April 2011) on the hiring of any temporary foreign workers by employers who have demonstrated non-compliance in the past (Maytree Foundation, 2011, p. 4). However, the structure of the LCP, which paves the path for 'bad' regulatory practices, remains unchanged, allowing for the potential exploitation and abuse of women caregivers. The following recommendations target reducing the scope of inequality and abuse for caregivers, and speeding up permanent residency and open permit procedures. If these recommendations are implemented, caregivers will be able to transition to the application process with the $\mathrm{CNO}$, faster and with higher rates of success.

\section{(1) Elimination of the mandatory live-in component of the LCP \\ Organizations such as the National Alliance of Philippine Women in Canada have} advocated for the complete elimination of the program. The federal government must modify the structure of the LCP, through the elimination of the mandatory live-in component of the LCP (Langevin \& Belleau, 2000, p. 42). This will allow caregivers to have enhanced protection of their employment rights, while escaping exploitation, unpaid overtime and forced labour. 


\section{(2) Enforcement of employment legislation governing live-in caregivers}

The Ministry of Labour must implement policy measures, which will increase the

enforcement of employment standard rights for caregivers. Worker's Action Center coordinator, Deena Ladd states that "[w]orkers should not be forced to take court action to recover unpaid wages, overtime and other employment standards entitlements" (Monsebraaten, 2011, para. 7). If this recommendation is implemented, caregivers will be able to complete the employment requirements (necessary for permanent residency and open work permit procedures), without fear of the termination of their employment.

\section{(3) Temporary foreign workers should be granted access to federally funded language training}

Currently migrant caregivers are not eligible for federally funded settlement services including language training (Maytree Foundation, 2011, p. 1). Providing eligibility to these services would allow internationally trained nurses to have higher English or French proficiency while working, allowing them to score higher on the language tests.

\section{RECOMMENDATIONS TO IMPROVE REGISTRATION REGULATION OF THE COLLEGES OF NURSES OF ONTARIO GOVERNING INTERNATIONAL APPLICANTS}

Internationally trained nurses take the indirect pathway to the nursing profession in Ontario. As noted earlier in the paper, the entry of internationally trained nurses into the provincial healthcare sector is much lower than that of Canadian trained nurses. In order to discuss the role immigration can play in addressing Ontario's labour market needs, the Ministry of Citizenship and Immigration has consulted with the Ministries of Finance, Training, Colleges and Universities and Economic Development and Innovation (Ministry of Citizenship and Immigration, 2012a, p. 5). Ontario’s immigration strategy forecasts an increase in the employment rates of highly skilled immigrants (Ministry of Citizenship and Immigration, 2012a, 
p. 11). This is related to current Canadian demographics, which demonstrate an aging population with low birth rates. The Ontario government's immigration strategy includes improvements in foreign qualification recognition of internationally trained professionals. They plan to collaborate with regulators and Ontario's Fairness Commissioner. Future projections for the shortage in healthcare professions indicate that by 2016 , Canada could be facing a shortage of 113,000 registered nurses (Owen \& Lowe, 2008, p. 30).

Similar collaboration among the various bodies involved in the accreditation process for internationally trained nurses must take place to ensure fair access to the nursing profession in Ontario. These bodies include university/college-bridging programs, the $\mathrm{CNO}$, third party assessors, Ministry of Citizenship and Immigration, the Ministry of Labour, the Ministry of Health and Long-term Care and the OFC. The Expert Roundtable on Immigration also agrees with the Ontario government's increased involvement in the collaboration with professional regulatory bodies, in the improvement of the assessment and recognition of internationally trained nurses qualifications (recommendation 30) (Ministry of Citizenship and Immigration, 2012 b, p. 3). Furthermore, it has been acknowledged that immigration, including the migration of internationally trained professions, including nurses, are vital to Ontario's economic and social well-being. If they are given fair access to accreditation procedures, internationally trained nurses who migrate to Canada as temporary foreign workers can prove to be assets for Ontario's economic wellbeing. In order to implement transparency and fairness in the registration regulation by the $\mathrm{CNO}$, the following recommendations should be considered for regulatory amendment. The recommendations below will work to positively impact all parties involved, including governmental bodies, regulatory bodies and internationally trained nurses. Ontario will be able to retain immigrants who possess high human capital and eliminate brain waste through 
inclusion of internationally trained nurses in Ontario's healthcare sector. This will additionally work to eliminate nursing shortages, and improve healthcare services for Ontarians.

\section{(1) The grandfathering of old registration requirements for old applicants}

Older applicants who filed applications with the CNO before January $1^{\text {st }}, 2013$ must be subject to the old regulations (Zubeida Ramji, personal communication, August 12, 2013). This will create a fairer licensing procedure for internationally trained applicants (and all applicants to the college alike) who were already in the system before the new amendments to the registration regulation.

\section{(2) Increasing the evidence of practice framework from three years to five years}

The CNO needs to change the evidence of practice framework from three years to five years. This will allow more internationally trained nurses to enter the nursing profession through indirect pathways, while retaining a safe evidence of practice (Registered Nurses' Association of Ontario, 2010, p. 7). More importantly, this will allow internationally trained nurses to (potentially) have their nursing education recognized by the $\mathrm{CNO}$ while not being prescribed bridging program to fill their education gaps.

\section{(3) Establishment of international mutual recognition agreements}

The CNO must establish international mutual recognition agreements for registered nurses and registered practical nurses to speed up the credentialing process to ensure qualified applicants receive license to practice nursing in Ontario. International mutual recognition agreements govern professional and credential recognition between two or more countries. International mutual recognition agreements will allow for free flowing labour mobility to move across international borders. The regulatory bodies should expand and establish international mutual recognition agreements with key source countries for their professions to reduce and 
remove the challenges for internationally trained applicants. In 2009, the Pan-Canadian

Framework for the Assessment and Recognition of Foreign Qualifications was introduced. This framework served as a public commitment by federal, provincial and territorial governments to guarantee that regulatory bodies implement principles of fairness, transparency, timeliness and consistency in their foreign- credential-recognition processes (Office of the Fairness Commissioner, 2008, p. 29). The CNO must amend its registration regulation to include this framework to implement much needed fairness and transparency into their registration regulation. The following recommendations should be implemented to remove barriers for nursing licensing and credential recognition for internationally trained nurses.

\section{(4) Introduction of targeted courses to fulfill specific education gaps}

This recommendation will allow applicants to address specific gaps without enrolling in whole program. The College must not send international applicants to 22-month bridging programs, which prove to be a financial burden as well as a time barrier nursing licensure (Singh $\&$ Sochan, 2010, p. 59). Applicants should only be required to complete the programs in which they have an active education gap. This will allow international applicants to re-enter the nursing profession faster in Ontario. 


\section{REFERENCES}

Andersen, G. E. (1990). Three Worlds of Welfare Capitalism. Princeton, New Jersey: Princeton University Press.

Arat-Koc, S. (2006). Whose Social Reproduction? Transnational Motherhood and Challenges to Feminist Political Economy. In Ed. Meg Luxton and Kate Bezanson (Eds.), Social

Reproduction: Feminist Political Economy Challenges Neo-liberalism (pp.75-92). Montreal, Quebec: McGill-Queen's Press.

Baumann, A. Blythe, J., McIntosh, K., \& Rheaume, A. (2006). Internationally Educated Nurses in Ontario: Maximizing the Brain Gain. Human Health Resources, 3. Retrieved from http://nhsru.com/publications/internationally-educated-nurses-in-ontario-maximizing-thebrain-gain-2

Constitution Act (982, c. 11 (U.K.), Schedule B). Retrieved from http://lawslois.justice.gc.ca/eng/const/page-15.html

CARE. (2013). History of CARE Centre for IENs. Retrieved from http://www.care4nurses.org/who-we-are/history-care/

Citizenship and Immigration Canada. (2013a). Extend your work permit — Live-in Caregivers. Retrieved from http://www.cic.gc.ca/english/work/caregiver/extend-stay.asp\#change

Citizenship and Immigration Canada. (2012b). Live-in Caregivers. Retrieved from http://www.cic.gc.ca/english/work/caregiver/

Citizenship and Immigration Canada (2013c). Who can apply for an Open Work Permit? Retrieved from http://www.cic.gc.ca/english/helpcentre/answer.asp?q=177\&t=17

Cohen, R. (2000). 'Mom is a stranger': The negative impact of immigration policies on the family life of Filipina domestic workers. Canadian Ethnic Studies, 32(3), 76-88. Retrieved from http://search.proquest.com.ezproxy.lib.ryerson.ca/docview/215638264

College of Nurses of Ontario. (2013a). Accepted Language Proficiency Tests. Retrieved from http://www.cno.org/en/become-a-nurse/new-applicants1/accepted-language-proficiencytests/

College of Nurses of Ontario. (2013b). Observational Structure Clinical Examination. Retrieved from http://www.cno.org/become-a-nurse/about-registration/entry-to-practiceexaminations/observational-structure-clinical-examination-osce/

College of Nurses of Ontario. (2013c). Registration Requirements for RNs and RPNs. Retrieved from http://www.cno.org/en/become-a-nurse/new-applicants 1/outside-canada/registrationrequirements-for-rns-and-rpns/ 
Connell, R. (2010). Understanding neoliberals. In Susan Bradley and Meg Luxton (eds.), Neoliberals \& Everyday Life (pp.22-36). Toronto: McGill-Queens University Press.

Cranford C. J., Vosko L. F., \& Zukewich N. (2003). Precarious Employment in the Canadian Labour Market: A Statistical Protrait. Just Labour, 3. Retrieved from http://www.justlabour.yorku.ca/index.php?volume=3\&page=cranfordetal

Czerniawski, B. (2013). Changes in the Registration Regulation: implications for nurses in Academic Practice [power point slides] Retrieved from http://www.cno.org/Global/4LearnAboutStandardsAndGuidelines/prac/learn/teleconferences/Changes\%20in\%20Registra tion\%20Regulation\%20teleconference\%20slides.pdf

Employment and Social Development Canada. (2010). Government of Canada helping internationally trained nurses enter the labour market: Canada's Economic Action Plan addresses labour market challenges, helps to improve quality of life. Retrieved from http://news.gc.ca/web/article-eng.do?nid=556009

Globe Editorial (2012, August 23). Helping the Nannies Live In. The Globe and Mail, pp. 10A.

G. Raymond Chang School of Continuing Education. (2009). Integrating Internationally Educated Professionals: Documenting University Bridging Programs in Ontario. Toronto, Ontario: Schalm, P., \& Guan J.

Health Force Ontario. (2013). Entry to Practice Requirements. Retrieved from http://www.healthforceontario.ca/en/Home/Nurses/Training_|_Practising_Outside_Ontario/P ractice_Requirements

Hick, S. (2007). Social Welfare in Canada: Understanding Income Security, Second Edition. Ottawa: Thompson Education Publishing.

Hodge, J. (2006). Unskilled Labour: Canada's Live-in Caregiver Program. Undercurrent, 3(2), 60-70. Retrieved from http://undercurrentjournal.ca

Immigration and Refugee Protection Regulations (SOR/2002-227). Retrieved from Justice Laws website: http://laws-lois.justice.gc.ca/eng/regulations/sor-2002-227/index.html

Kingfisher, C. (2002). Neoliberalism II. In Catherine Kingfisher (Eds.), Western Welfare in Decline: Globalization and Women's Poverty (pp.32-48). Philadelphia: University of Pennsylvania Press.

Kolawole, B. (2009). Ontario's internationally educated nurses and waste in human capital. International Nursing Review, 56. Retrieved from http://onlinelibrary.wiley.com.ezproxy.lib.ryerson.ca/doi/10.1111/j.14667657.2008.00666.x/full

Langevin, L., \& Belleau, M. C. (2000). Trafficking in Women in Canada: A Critical Analysis of the Legal Framework Governing Immigrant Live-in Caregivers and Mail-Order Brides. 
Retrieved from the Government of Canada Publications website: http://publications.gc.ca/collections/Collection/SW21-83-2001E.pdf

Maytree Foundation. (2011). The "Pilot" for recruiting temporary foreign workers for lowskilled jobs should be abolished. (Discussion paper). Retrieved from http://docs.maytree.com/discussionpapers/adjustingthebalance/2-tfw_pilot.pdf

Ministry of Citizenship and Immigration. (2012a). A New Direction: Ontario's Immigration Strategy. Ottawa, Ontario: Queen's Printer for Ontario.

Ministry of Citizenship and Immigration. (2012b). Expanding Our Routes To Success: The Final Report By Ontario's Expert Roundtable On Immigration. Ottawa, Ontario: Queen's Printer for Ontario.

Ministry of Labour. (2012). Your Employment Standard Rights, Foreign National Live-in Caregivers: Information Sheet. Ottawa, Ontario: Queen's Printer for Ontario.

Monsebraaten, L. (2011, May 29). The Toronto Star. Retrieved from http://www.thestar.com/news/gta/2011/05/29/caregiver_sues_former_employer_claiming_1 62000_in_lost_wages.html

Office of the Fairness Commissioner. (2008). Study of Registration Practices of the College of Nurses of Ontario, 2007. Ottawa, Ontario: Queen's Printer for Ontario.

Office of the Fairness Commissioner. (2013). A Fair Way to Go: Access to Ontario's Regulated Professions and the Need to Embrace Newcomers in the Global Economy. Ottawa, Ontario: Queen's Printer for Ontario.

Omidvar, R. (March 2009). Tough Choices for Migrant Workers

(Opinion 6). Retrieved from http://maytree.com/maytreeopinion/MaytreeOpinion6.pdf

Owen, T., \& Lowe, S. J. (2008). Labour Market Integration of Skilled Immigrants: Good Practices for the Recognition of International Credentials-Canada. Retrieved from http://unesdoc.unesco.org/images/0017/001798/179835e.pdf

Hondagneu-Sotelo P., \& Avila E. (1997)."I'm Here, but I'm There": The Meanings of Latina Transnational Motherhood. Gender and Society, 11(5). Retrieved from http://journals2.scholarsportal.info.ezproxy.lib.ryerson.ca/detailssfx.xqy?uri=/08912432/v11i0005/548_hbit.xml

Regulations Amending the Immigration and Refugee Protection Regulations. (2010). Canadian Gazette, Part II, April 1, 2010, vol. 144, no. 8. (SOR /2010-78). Retrieved from http://gazette.gc.ca/rp-pr/p1/2010/2010-02-20/pdf/g1-14408.pdf

Registered Nurses Association of Ontario. (2010). RNAO's Response to CNO re: the proposed Nursing Registration Regulation. Retrieved from http://rnao.ca/sites/rnao-ca/files/R. 
NAO_CNO_Registration_Regulation_Response_-_FINAL.pdf

Singh, S. (2012, Fall). Canada's Live-in Caregiver Program Applies Unfair Restrictions on Women who Work as Caregivers and Should be Scrapped, Says Cecelia Diocson of the National Alliance of Philippine women in Canada. Herizons, 26(2), 18-23.

Singh, M. D., and Sochan, A. (2010). Voices of internationally educated nurses: policy recommendations for credentialing. International Nursing Review, 57. Retrieved from http://onlinelibrary.wiley.com.ezproxy.lib.ryerson.ca/doi/10.1111/j.14667657.2009.00759.x/full

Spitzer, D., and Torres, S. (2008). GENDER-BASED BARRIERS TO SETTLEMENT AND INTEGRATION FOR LIVE-IN-CAREGIVERS: A REVIEW OF THE LITERATURE. The CERIS Working Paper Series, 71. Retrieved from http://ceris.metropolis.net/Virtual\%20Library/WKPP\%20List/WKPP2008/CWP71.pdf

Sutherland, J. (2008). Temporary Foreign Worker Program [powerpoint slides]. Retrieved from http://www.metropolis.net/policypriority/migration_seminar/JamesSutherlandsPresentation e.pt

Walton-Roberts, M., and Hennebry, J. (2012). Indirect pathways into practice: A comparative examination of Indian and Philippine internationally educated nurses and their entry into Ontario's nursing profession. The CERIS Working Paper Series, 92. Retrieved from http://www.ceris.metropolis.net/wp-content/uploads/2012/10/Final-Report-Walton_RobertsCERIS.pdf

Vosko, L.F. (2003). Employment in Canada: Taking Stock, Taking Action. Just Labour, 3. Retrieved from http://www.justlabour.yorku.ca/volume3/pdfs/vosko.pdf

Vosko, L. F., \& Clark, L. F. (2009) Gendered Precariousness and Social Reproduction. In L. Vosko et al. (Eds.), Gender and the Contours of Precarious Employment (pp.26-42). London, England: Routeledge. 